\title{
PERAN PEMERINTAH MELALUI DINAS KESEHATAN KABUPATEN SUMBAWA BARAT DALAM MENYOSIALISASIKAN BAHAYA MERKURI BAGI KESEHATAN DI KECAMATAN BRANG REA
}

\author{
Yusmawati ${ }^{1}$, Restiawan Permana ${ }^{2}$ \\ ${ }^{1}$ Fakultas Komunikasi dan Bahasa, Universitas Bina Sarana Informatika, Indonesia \\ yusmawati.ymw@bsi.ac.id \\ ${ }^{2}$ Universitas Pakuan, Indonesia \\ restiawan.pmn@gmail.com
}

\begin{abstract}
Abstrak
Banyaknya penambang emas rakyat tanpa izin (ilegal) terjadi di Kabupaten Sumbawa Barat khususnya di Kecamatan Brang Rea. Hal ini mengakibatkan air sungai tercemar zat merkuri oleh limbah pertambangan tersebut. Pencemaran ini tentunya mengancam kesehatan masyarakat di sana. Rumusan masalah dalam penelitian ini adalah peran pemerintah melalui Dinas Kesehatan Kabupaten Sumbawa Barat dalam menyosialisasikan bahaya merkuri bagi kesehatan masyarakat di Kecamatan Brang Rea. Pendekatan yang digunakan dalam penelitian ini adalah kualitatif. Sedangkan jenis penelitian ini menggunakan metode deskriptif. Komunikasi kesehatan memerlukan metode dan media agar pesan dapat tersampaikan dengan baik. Metode komunikasi tatap muka yang dilakukan tenaga kesehatan berupa penyuluhan kesehatan yang pesannya berisi bahaya merkuri bagi kesehatan. Selain metode komunikasi tatap muka, dibutuhkan juga media komunikasi kesehatan berupa poster. Poster dipilih oleh Puskesmas Brang Rea dalam kegiatan komunikasi kesehatannya dengan alasan bahwa poster cocok digunakan sebagai tindak lanjut dari suatu pesan yang sudah disampaikan beberapa waktu yang lalu. Dengan demikian poster bertujuan untuk mengingatkan kembali dan mengarahkan pembaca ke arah tindakan tertentu sesuai dengan apa yang diinginkan oleh komunikator.

Kata kunci: peran pemerintah, komunikasi kesehatan, merkuri.
\end{abstract}

\begin{abstract}
The number of unlicensed (illegal) community gold miners occurs in West Sumbawa Regency, especially in Brang Rea District. This results in river water being polluted with mercury by the mining waste. Creation of public health problems there. The formulation of the problem in this study is the role of the government through the West Sumbawa Regency Health Office in socializing the dangers of mercury for public health in the District of Brang Rea? The purpose of this study was to study how the government through the West Sumbawa District Health Office in socializing the dangers of mercury for public health in the District of Brang Rea. The approach used in this research is qualitative. While this type of research uses descriptive methods. Health communication requires methods and media so that messages can be conveyed properly. Face to face communication methods conducted by health workers in the form of health education with messages containing mercury hazards to health. In addition to face-to-face communication methods, health communication media such as posters are also needed. The poster was chosen by the Brang Rea Health Center in its health communication activities on the grounds that the poster is suitable to be used as a follow up to a message that was delivered some time ago. Thus the poster aims to remind and direct the reader towards certain actions in accordance with what is desired by the communicator.

Keywords: the role of government, health communication, mercury.
\end{abstract}




\section{PENDAHULUAN}

Maraknya pertambangan rakyat di beberapa wilayah Indonesia menyebabkan terjadinya pencemaran lingkungan khususnya air karena mengandung merkuri, salah satunya di Kecamatan Brang Rea Kabupaten Sumbawa Barat (KSB). Kegiatan penambangan rakyat yang dilakukan oleh masyarakat di Kecamatan Brang Rea sudah berlangsung cukup lama. Dengan potensi alam yang sangat besar, masyarakat tidak tinggal diam. Mereka mulai berpikir bagaimana mengoptimalkan kekayaan alam di sana agar bisa dimanfaatkan. Keberadaan pertambangan ini sangat berpengaruh pada perekonomian masyarakat Sumbawa Barat. Karena pertambangan ini bersifat perorangan, maka seringkali kegiatannya dianggap ilegal karena tidak sesuai dengan prosedur yang berlaku dalam kegiatan pertambangan. Terutama dalam hal pengelolaan limbahnya. Dengan berbagai keterbatasan tersebut, pertambangan ini menjadi ancaman juga bagi kesehatan masyarakat di sana karena membawa dampak negatif bagi kesehatan.

Kini, kondisi di atas menjadi perhatian banyak pihak karena mengancam kesehatan masyarakat. Dari sekian kasus yang selama ini ditangani oleh Dinas Kesehatan KSB, sebagian besar disebabkan oleh pengaruh zat merkuri yang dipakai oleh penambang emas tanpa pengaman. Dari hasil laboratorium, masyarakat di Brang Rea sekitar 70\% tubuhnya terdampak merkuri, dan Dinas Kesehatan memberikan warning akibat dari zat kimia yang dipakai oleh penambang demi kesehatan masyarakat di sana (Rozak, 2019). Secara spesifik pencemaran pada tanaman padi ditemukan kadar merkuri sebesar 0,37 miligram atau di atas ambang batas dari batas aman sebesar 0,3 miligram. Begitu juga daging kuda, ditemukan kadar merkuri di atas 0,3 miligram sesuai standar kesehatan lingkungan yang ditetapkan. Sementara pada manusia, berdasarkan sampel yang diambil rata-rata di rambut mereka ditemukan kandungan merkuri dan tingkat anemia yang diderita juga meningkat secara signifikan (Sumbawa2, 2012).

Masalah kesehatan menjadi tanggung jawab pemerintah untuk mewujudkan pembangunan kesehatan yang baik dan merata. Kesehatan menjadi salah satu isu penting dalam pembangunan yang berorientasi pada manusia. Sektor ini menjadi barometer dalam melihat tingkat kemajuan suatu daerah. Kualitas kesehatan di suatu wilayah sangat ditentukan oleh berbagai sarana dan prasarana yang disediakan oleh penyelenggara pembangunan, salah satunya adalah puskesmas, tenaga kesehatan serta berbagai sarana pendukung lainnya. Puskesmas merupakan unit penyelenggara pelayanan kesehatan masyarakat yang dibangun di 
tiap kecamatan. Peraturan Menteri Kesehatan Republik Indonesia Nomor 75 Tahun 2014 tentang puskesmas adalah fasilitas pelayanan kesehatan yang menyelenggarakan upaya kesehatan masyarakat dan upaya kesehatan perseorangan tingkat pertama, dengan lebih mengutamakan upaya promotif dan preventif, untuk mencapai derajat kesehatan masyarakat yang setinggi-tingginya di wilayah kerjanya (Permenkes, 2014).

Dengan adanya otonomi daerah, pemerintah daerah memiliki kewenangan untuk mengatasi berbagai masalah sesuai dengan karakteristik alam dan juga masyarakatnya. Oleh sebab itu, puskesmas yang tersebar di setiap kecamatan berupaya memberikan informasi tentang kesehatan dengan mengedukasi dan melakukan sosialisasi tentang kesehatan yang bertujuan untuk meningkatkan pemahaman masyarakat. Aktivitas ini biasa disebut komunikasi kesehatan. Dengan komunikasi kesehatan, tidak hanya proses penyadaran masyarakat atau pemberian dan peningkatan pengetahuan masyarakat tentang kesehatan saja, namun juga adanya upaya bagi perubahan perilaku masyarakat. Dari sini tampak bahwa faktor komunikasi sangat penting untuk dilakukan oleh tenaga kesehatan. Komunikasi yang dimaksud tidak semata soal instrumen yang dipakai, tetapi lebih pada bagaimana memberi pemahaman dan meyakinkan nilai-nilai dan pandangan budaya menyangkut kesehatan.

Permasalahan lain yang sering ditemukan dalam pembangunan kesehatan adalah rendahnya kesadaran masyarakat akan pentingnya nilai kesehatan. Rendahnya kesadaran ini berkaitan dengan minimnya pengetahuan tentang suatu jenis penyakit dan pengamalan perilaku hidup sehat. Oleh sebagian orang, penyakit dianggap sebagai takdir atau hukuman atas perbuatan manusia itu sendiri. Selain itu, kesehatan bagi sebagian besar masyarakat juga masih dimaknai sebagai hal yang perlu diperhatikan apabila keberadaannya sudah mengancam atau mulai terserang penyakit. Sementara, upaya-upaya pencegahan (preventive action) masih dianggap tidak penting dan belum menjadi kebiasaan. Masalah ini melanda hampir seluruh lapisan masyarakat tanpa mempedulikan latar belakang ekonomi maupun pendidikan mereka.

Berdasarkan penelitian tentang pengetahuan masyarakat terhadap kesehatan, bahwa kurangnya pengetahuan tentang kesehatan mengakibatkan adanya keengganan bahkan ketakutan pada masyarakat untuk mengunjungi layanan kesehatan seperti rumah sakit. Secara akumulatif hal ini membuat kesenjangan yang cukup besar antara pemberi layanan kesehatan (termasuk rumah sakit) dan masyarakat. Ketakutan tersebut juga kadang berdasarkan ketidakpercayaan masyarakat terhadap layanan kesehatan di Indonesia, sehingga mereka 
lebih memilih untuk menggunakan alternatif lain atau bahkan berobat keluar negeri (Dewi, 2013). Penelitian lainnya juga menunjukkan bahwa terdapat faktor yang memengaruhi masyarakat, yaitu faktor sosial budaya. Budaya (tradisi atau kebiasaan) dalam kesehatan masyarakat adalah dalam membentuk, mengatur dan memengaruhi tindakan atau kegiatan untuk memenuhi berbagai kebutuhan kesehatan. Tingkat kepercayaan masyarakat kepada petugas kesehatan yang masih rendah dan tingginya kepercayaan masyarakat terhadap dukun yang karismatik mendorong daya tarik masyarakat untuk lebih memilih dukun sebagai pilihan pengobatan dan pertolongan persalinan (Sya'ban, 2013).

Berdasarkan uraian-uraian di atas, maka rumusan masalah dalam penelitian ini adalah bagaimana peran pemerintah melalui Dinas Kesehatan Kabupaten Sumbawa Barat dalam menyosialisasikan bahaya merkuri bagi kesehatan masyarakat di Kecamatan Brang Rea? Adapun tujuan penelitian ini dilakukan adalah untuk mengetahui bagaimana peran pemerintah melalui Dinas Kesehatan Kabupaten Sumbawa Barat dalam menyosialisasikan bahaya merkuri bagi kesehatan masyarakat di Kecamatan Brang Rea.

Secara teoretis, manfaat dari hasil penelitian ini diharapkan mampu memberikan kontribusi berupa informasi, data, fakta, dan analisis terhadap studi-studi yang berkaitan dengan kajian komunikasi kesehatan. Diharapkan juga, penelitian ini dapat memperkaya kajian dan memperluas aspek-aspek teori komunikasi yang sudah ada dengan menambah temuan baru atau memperkuat teori yang sudah ada sehingga dapat menunjang penelitian sejenis pada waktu yang akan datang. Sedangkan secara praktis, penelitian ini diharapkan mampu melengkapi informasi yang dibutuhkan masyarakat dan membantu mereka memperoleh panduan atau referensi tentang perawatan kesehatan, serta membangun kemampuan komunikasi dalam berinteraksi dengan tenaga kesehatan di tingkat puskesmas. Penelitian ini sangat penting dilakukan karena mampu memberikan sumbangan berupa hasil penelitian dan pemikiran kepada pengembangan ilmu komunikasi dan kebijakan publik khususnya. Bagi pemerintah, penelitian ini diharapkan dapat memberi masukan dalam pembuatan kebijakan terkait masalah kesehatan dan lingkungan. Sedangkan bagi pelaku usaha pertambangan rakyat, penelitian ini diharapkan mampu memberikan pemahaman agar mereka memenuhi standarisasi atau aturan tentang bagaimana mengelola limbah dari tambang yang mereka jalani agar tidak merusak ekosistem di wilayah pemukiman masyarakat. 
Komunikasi kesehatan merupakan studi yang menekankan peranan teori komunikasi yang dapat digunakan dalam penelitian dan praktek yang berkaitan dengan promosi kesehatan dan pemeliharaan kesehatan. Komunikasi merupakan salah satu aspek dalam interaksi antara manusia, yang bermanfaat dalam mendukung kegiatan dalam kehidupan sehari-hari. Aksioma komunikasi, menyatakan bahwa "seseorang tidak dapat tidak berkomunikasi" (a person cannot not communicate) (Pace dan Faules, 2002). Oleh sebab itu, komunikasi sebagai faktor yang memengaruhi dalam berbagai kegiatan masyarakat yang bersifat sosial, ekonomi maupun politik. Secara umum, West dan Turner mengemukakan bahwa komunikasi adalah proses sosial di mana individu-individu menggunakan simbolsimbol untuk menciptakan dan menginterpretasikan makna dalam lingkungan mereka (West dan Turner, 2008).

Komunikasi adalah sebuah proses pernyataan antarmanusia. Pernyataan yang dimaksud adalah dapat berupa pikiran atau perasaan seseorang yang disampaikan kepada orang lain dan pernyataan tersebut disampaikan dengan menggunakan bahasa sebagai alat penyalurnya (Effendy, 2003). Sementara Rogers menyatakan bahwa komunikasi adalah proses dimana suatu ide dialihkan dari sumber kepada suatu penerima atau lebih, dengan maksud untuk mengubah tingkah laku mereka. Pendapat tersebut hampir sama dengan pendapat yang dikemukakan oleh Hovland yang mendefinisikan komunikasi sebagai proses yang memungkinkan seseorang (komunikator) menyampaikan rangsangan untuk mengubah perilaku orang lain. Berbeda dengan pendapat yang dikemukakan oleh Rogers dan Hovland, Laswell menerangkan bahwa komunikasi pada dasarnya merupakan suatu proses yang menjelaskan siapa, mengatakan apa, dengan saluran apa, kepada siapa? Dengan akibat apa dan hasil apa? Atau lebih dikenal dengan "Who Says What Which in Channel to Whom With What Effect?". Dalam rumus Laswell tersebut terdapat beberapa pertanyaan yang arus dijawab. Jawaban dari pertanyaan tersebut merupakan komponen-komponen yang saling berkaitan satu sama lain (dalam Mulyana, 2008).

Proses komunikasi terbagi menjadi dua tahap, yaitu proses komunikasi secara primer dan sekunder. Proses komunikasi secara primer adalah proses penyampaian pikiran oleh komunikator kepada komunikan dengan menggunakan suatu lambang (symbol) sebagai media atau saluran. Lambang ini umumnya bahasa, tetapi dalam situasisituasi komunikasi tertentu lambang-lambang yang digunakan dapat berupa kial (gesture), yakni gerak anggota tubuh, gambar, warna, dan lain sebagainya. Sedangkan proses 
komunikasi secara sekunder adalah proses penyampaian pesan oleh komunikator kepada komunikan dengan menggunakan alat atau sarana sebagai media kedua setelah memakai lambang sebagai media pertama. Media yang digunakan adalah surat, telepon, surat kabar, radio atau televisi (Effendy, 2003).

Tujuan mempelajari ilmu komunikasi, dapat dikategorikan kedalam dua hal, yaitu; aspek umum dan aspek khusus. Aspek pertama, bertujuan untuk memperoleh pemahaman tentang ilmu yang terkait dengan proses komunikasi. Melalui pemahaman ini para ilmuwan dan pelaku komunikasi diharapkan akan dapat melakukan komunikasi dengan baik dan selalu mengalami perubahan dan kemajuan dalam berkomunikasi. Aspek kedua, diharapkan akan dapat menuntun manusia untuk dapat: mengubah sikap (to change the attitude); mengubah opini/pendapat/pandangan (to change the opinion); mengubah perilaku (to change the behavior); dan mengubah masyarakat (to change the society).

Komunikasi tidak saja berkutat pada persoalan pertukaran berita dan pesan, akan tetapi juga melingkupi kegiatan individu dan kelompok terkait dengan tukar menukar data, fakta dan ide. Bila dilihat dari makna ini, ada beberapa fungsi yang melekat dalam proses komunikasi: Pertama, informasi, pengumpulan, penyimpanan, pemrosesan, penyebaran berita, data, gambar, fakta, pesan, opini, dan komentar yang dibutuhkan agar dapat dimengerti dan beraksi secara jelas terhadap kondisi lingkungan dan orang lain agar dapat mengambil keputusan yang tepat. Kedua, sosialisasi (pemasyarakatan), penyedian sumber ilmu pengetahuan yang memungkinkan orang bersikap dan bertindak sebagai anggota masyarakat yang efektif sehingga ia sadar akan fungsi sosialnya dan dapat aktif di dalam masyarakat. Ketiga, motivasi, menjelaskan tujuan setiap masyarakat jangka pendek maupun jangka panjang, mendorong orang untuk menentukan pilihan dan keinginannya, mendorong kegiatan individu dan kelompok berdasarkan tujuan bersama yang akan dikejar. Keempat, perdebatan dan diskusi, menyediakan dan saling menukar fakta yang diperlukan untuk memungkinkan persetujuan atau menyelesaikan perbedaan pendapat mengenai masalah publik, menyediakan bukti-bukti relevan yang diperlukan untuk kepentingan umum agar masyarakat lebih melibatkan diri dengan masalah yang menyangkut kepentingan bersama. Kelima, pendidikan, pengalihan ilmu pengetahuan dapat mendorong perkembangan intelektual, pembentukan watak, serta membentuk keterampilan dan kemahiran yang diperlukan pada semua bidang kehidupan. Keenam, memajukan kehidupan, 
menyebarkan hasil kebudayaan dan seni dengan maksud melestarikan warisan masa lalu, mengembangkan kebudayaan dengan memperluas hormon seseorang serta membangun imajinasi dan mendorong kreatifitas dan kebutuhan estetiknya. Ketujuh, hiburan, penyebarluasan sinyal, simbol, suara, dan imaji dari drama, tari, kesenian, kesusastraan, musik, olahraga, kesenangan, kelompok, dan individu. Kedelapan, Integrasi menyediakan bagi bangsa, kelompok, dan individu kesempatan untuk memperoleh berbagai pesan yang mereka perlukan agar mereka dapat saling kenal dan mengerti serta menghargai kondisi pandangan dan keinginan orang lain. Sedangkan beberapa tujuan komunikasi yang umumnya dilakukan adalah melakukan: perubahan sikap (attitude change); perubahan pendapat (opinion change); perubahan perilaku (behavior change); dan perubahan sosial (social change) (Mulyana, 2008).

Komunikasi berkaitan erat dengan kehidupan sehari-hari, termasuk juga dalam dunia kesehatan. Kita menyadari pentingnya komunikasi bagi profesional medis untuk meningkatkan pelayanan dengan meningkatkan keterampilan komunikasi mereka. Setengah abad yang lalu, Michael Balint menyatakan bahwa obat yang paling efektif dalam praktek medis adalah dokter itu sendiri. Keterampilan komunikasi ini bukan bawaan, melainkan dapat dipelajari (Bensing dan Verhaak, 2004).

Komunikasi kesehatan menurut Littlejohn adalah ranah khusus pada ilmu komunikasi yang mengkaji peranan penting komunikasi dan interaksi manusia dalam menyampaikan pesan-pesan komunikasi untuk promosi kesehatan individu maupun kesehatan publik (Littlejohn, 2009). Sementara menurut Kotler dan Zaltman, komunikasi kesehatan termasuk pada ranah social-marketing, yaitu penggunaan prinsip dan strategi marketing untuk menjual ide-ide sosial, mengubah cara pandang dan perilaku masyarakat. Kesehatan adalah salah satu ide sosial yang dimaksud. Pemasaran sosial (social marketing) adalah sebuah desain, implementasi, dan evaluasi program yang bertujuan untuk memengaruhi penerimaan masyarakat tentang ide-ide sosial dan meliputi pertimbangan dalam perencanaan produk, penentuan harga, strategi komunikasi, mekanisme distribusi, dan riset pemasaran (Kotler dan Zaltman, 1971).

Schivo mendefinisikan komunikasi kesehatan sebagai "Health communication is a multifaceted and multidisciplinary approach to reach different audiences and share healthrelated information with the goal of influencing, engaging, and supporting individuals, communities, health professionals, special groups, policy makers and the public to champion, 
introduce, adopt, or sustain a behavior, practice, or policy that will ultimately improve health outcomes (Komunikasi kesehatan adalah keragaman dan pendekatan multidisiplin untuk menjangkau khalayak yang berbeda dan berbagi informasi terkait kesehatan dengan tujuan mempengaruhi, melibatkan, dan mendukung individu, komunitas, profesional kesehatan, kelompok khusus, pembuat kebijakan dan masyarakat untuk memperjuangkan, memperkenalkan, mengadopsi, atau mempertahankan perilaku, praktik, atau kebijakan yang pada akhirnya akan meningkatkan hasil kesehatan)" (Schivo, 2007).

Sebagai sebuah bidang baru dalam keilmuan, komunikasi kesehatan yang baru diperkenalkan pada 1991 memicu bermacam kontroversi mengenai keberadaannya, terutama mengenai korelasi kesehatan dan komunikasi yang seakan-akan terlalu mengada-ada. Kesehatan adalah ilmu pasti yang berdasar pada scientific-paradigm, sementara komunikasi adalah cabang ilmu sosial yang memandang segala hal adalah hasil dari konstruksi manusia yang didapat dari interaksi dengan diri dan lingkungan.

Konferensi Komunikasi Kesehatan pertama kali diadakan di Toronto tahun 1991. Menghasilkan delapan pernyataan mengenai relevansi praktek komunikasi dengan kesehatan, yaitu: 1) Permasalahan komunikasi dalam praktek-praktek medis adalah persoalan krusial yang sering terjadi; 2) Rasa cemas dan ketidakpuasan pasien disebabkan oleh ketidakpastian dan minimnya informasi, penjelasan, maupun feedback; 3) Dokter sering salah mempersepsi tentang informasi seperti apa yang dibutuhkan dan diinginkan oleh pasien; 4) Peningkatan kualitas komunikasi berkaitan dengan kondisi kesehatan pasien; 5) Pasien harus mendapatkan penjelasan dan pemahaman, meskipun itu adalah hal yang tidak dapat diatasi dan dapat menimbulkan kecemasan; 6) Semakin besar partisipasi pasien dalam setiap pertemuan dengan dokter meningkatkan derajat kepuasan, dan pada akhirnya membantu proses penyembuhan pasien; 7) Level stress psikologis pada pasien penderita penyakit kronis berkurang ketika mereka percaya bahwa informasi yang mereka dapatkan memadai; 8) Manfaat komunikasi kesehatan dapat dirasakan dalam pertemuan klinis dokter-pasien tanpa perlu dilakukannya sesi khusus, asalkan dokter belajar teknik yang relevan (Berry, 2007).

Berikut adalah empat karakteristik komunikasi kesehatan yang membuatnya berbeda dengan bentuk-bentuk komunikasi lainnya: 1) Interaksi antara tubuh dan komunikasi; 2) Interaksi science dan humanism; 3) Interaksi antara idiosyncracy dan communality; 4) Interaksi antara (un)certainty and values, expectations, and desires (Bobrow dan Matson, 
2003). Fokus dalam komunikasi kesehatan adalah transaksi spesifik pada isu-isu yang berhubungan dengan kesehatan dan faktor-faktor yang memperngaruhi transaksi tersebut. Transaksi yang berlangsung antar ahli kesehatan dan antara ahli kesehatan dengan klien merupakan perhatian utama dalam komunikasi kesehatan. Tujuan pokok program komunikasi kesehatan adalah perubahan perilaku kesehatan dalam rangka meningkatkan derajat kesehatan. Dengan adanya intervensi komunikasi kesehatan, diharapkan dapat menumbuhkan permintaan terhadap produk dan atau pelayanan kesehatan yang dibutuhkan, seperti Keluarga Berencana, kelangsungan Hidup Anak, Pencegahan penyakit Infeksi yang aman dan efektif, dan lain-lain. Dalam proses ini, masyarakat termasuk Rumah Tangga Sangat Miskin (RTSM), ditempatkan pada posisi yang penting dan menentukan. Upaya menumbuhkan permintaan terhadap pelayanan kesehatan merupakan efek dari proses komunikasi yang memberikan informasi kepada anggota masyarakat bahwa telah tersedia pelayanan kesehatan yang mereka butuhkan, mudah didapat dan digunakan. Informasi tersebut diharapkan dapat mengubah perilaku masyarakat yang semula tidak pernah memanfaatkan pelayanan kesehatan karena tidak tahu, kemudian saat ini, setelah mendapatkan informasi, hal itu menjadi kebutuhan (Notoatmodjo, 2005).

Berdasarkan berbagai definisi di atas tentang komunikasi kesehatan, maka dipahami secara umum bahwa komunikasi tersebut merujuk pada segala upaya memberikan informasi kesehatan, mempromosikan gaya hidup sehat, dan segala bentuk transfer informasi kesehatan yang terencana dan strategis. Pada perkembangannya, titik perhatian komunikasi kesehatan melebar pada kajian strategi komunikasi untuk menginformasikan dan memengaruhi keputusan individu maupun komunitas dalam upaya-upaya meningkatkan kesehatan mereka.

Komunikasi kesehatan untuk masyarakat lebih mengarah pada bentuk promosi kesehatan. Promosi kesehatan bukan hanya proses penyadaran komunitas masyarakat dalam hal pemberian dan peningkatan pengetahuan dalam bidang kesehatan saja. Promosi kesehatan merupakan program kesehatan yang dirancang untuk membawa perbaikan berupa perubahan perilaku, baik di dalam masyarakat maupun lingkungan organisasi. Untuk dapat mewujudkan promosi kesehatan, diperlukan suatu strategi yang baik. Strategi adalah cara yang digunakan dalam mencapai apa yang diinginkan dalam promosi kesehatan. Strategi ini diperlukan dalam mewujudkan promosi kesehatan dan tercermin dalam tiga langkah, yaitu: 1) Advokasi. Merupakan kegiatan memberikan bantuan informasi kesehatan kepada masyarakat melalui pihak pembuat keputusan dan penentu kebijakan dalam bidang kesehatan; 2) Dukungan 
sosial. Promosi kesehatan akan mudah dilakukan bila mendapat dukungan dari berbagai elemen yang ada di masyarakat. Dukungan masyarakat antara lain dari unsur informal (tokoh agama dan tokoh adat) dan unsur formal (petugas kesehatan, pejabat pemerintah); 3) Pemberdayaan masyarakat (empowerment community). Pemberdayaan masyarakat dibutuhkan supaya masyarakat memperoleh kemampuan dalam memelihara dan meningkatkan kesehatan. Upaya ini antara lain dapat dilakukan melalui penyuluhan kesehatan (Mubarak dan Iqbal, 2009).

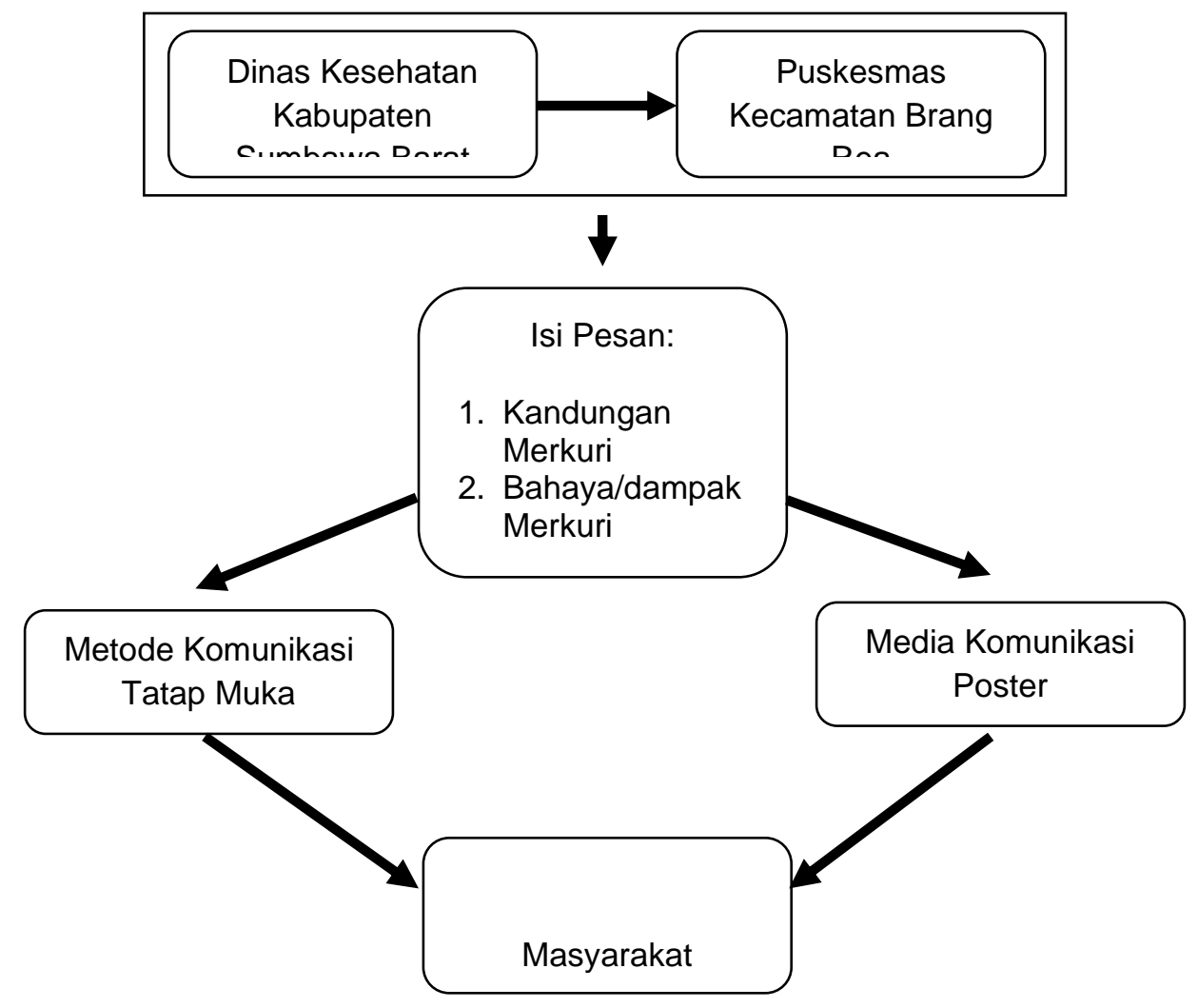

Gambar 1. Kerangka Pemikiran

\section{METODELOGI}

Pendekatan yang digunakan dalam penelitian ini adalah kualitatif, yaitu sebuah proses penyelidikan untuk memahami masalah sosial atau masalah manusia berdasarkan pada penciptaan gambar holistik yang dibentuk dengan kata-kata, melaporkan pandangan informan secara rinci, dan disusun dalam sebuah latar ilmiah (Creswell, 2010). Penelitian kualitatif merupakan fokus perhatian dengan beragam metode yang mencakup pendekatan interpretif dan naturalistik terhadap subjek kajiannya. Artinya, para peneliti kualitatif mempelajari benda-benda dalam konteks alaminya, yang berupaya untuk memahami dan menafsirkan 
fenomena dilihat dari sisi makna yang dilekatkan manusia kepadanya (Denzin dan Lincoln, 2009).

Sedangkan jenis penelitian ini menggunakan metode deskriptif, yaitu mendeskripsikan secara sistematis, faktual, dan akurat tentang fakta-fakta dan sifat-sifat populasi atau subyek penelitian. Metode deskriptif diwujudkan dengan penggambaran secara mendalam tentang situasi dan proses yang diteliti. Karena sifat penelitiannya seperti ini, maka penelitian kualitatif tidak berusaha untuk menguji hipotesis. Penelitian deskriptif mempelajari masalahmasalah dalam masyarakat, serta tata cara yang berlaku dalam masyarakat serta situasi-situasi tertentu, termasuk tentang hubungan, kegiatan-kegiatan, sikap-sikap, pandangan-pandangan, serta proses-proses yang sedang berlangsung dan pengaruh-pengaruh dari suatu fenomena. Jadi, penelitian deskriptif hanyalah memaparkan situasi atau peristiwa (Rakhmat, 2000).

Penelitian dilaksanakan di Desa Beru Kecamatan Brang Rea Kabupaten Sumbawa Barat Nusa Tenggara Barat. Adapun yang dijadikan informan kunci dalam penelitian ini adalah petugas/tenaga kesehatan yang bertugas di Puskesmas Desa Beru. Sedangkan yang menjadi informan lainnya adalah anggota masyarakat setempat sekaligus sebagai penambang emas rakyat. Semua informan ini dilihat dapat mewakili apa yang ingin diteliti, serta semuanya dipilih berdasarkan pada konteks yang peneliti ingin bahas dalam penelitian ini. Sedangkan subjek penelitian ini adalah komunikasi kesehatan yang dilakukan oleh tenaga kesehatan kepada masyarakat dalam menyosialisasikan bahaya merkuri bagi kesehatan khususnya di Kecamatan Brang Rea KSB.

Instrumen penelitian dalam penelitian ini adalah peneliti sendiri, selanjutnya setelah fokus penelitian menjadi jelas, diharapkan dapat melengkapi data dan membandingkan dengan data yang telah ditemukan melalui wawancara dan alat bantu yang digunakan dalam proses wawancara adalah tape recorder sebagai alat perekam suara, pulpen, pedoman wawancara, dan kamera untuk dokumentasi.

Data yang digunakan dalam penelitian ini terdiri dari data primer dan sekunder. Data primer diperoleh dengan cara melakukan observasi dan wawancara. Sedangkan data sekunder diperoleh dari referensi berupa studi pustaka, dan dokumentasi. Setelah data diperoleh, langkah selanjutnya adalah mengorganisasi data sehingga hasil olahannya nanti dapat 
dianalisis. Pengolahan data kualitatif ada empat tahapan, yaitu: mentranskripsi data, mengorganisasi data, membaca kembali data, dan mengkategorisasi data.

Menurut Miles dan Huberman terdapat tiga alur analisis data kualitatif, yaitu reduksi data, penyajian data, dan penarikan kesimpulan (dalam Sugiyono, 2008). Reduksi data adalah proses pemilihan, pemusatan perhatian pada penyederhanaan, pengabstrakan, dan transformasi data kasar yang muncul dari catatan-catatan tertulis di lapangan. Proses ini berlangsung terus menerus selama penelitian berlangsung, bahkan sebelum data benar-benar terkumpul sebagaimana terlihat dari kerangka konseptual penelitian, permasalahan studi, dan pendekatan pengumpulan data yang dipilih peneliti. Setelah data direduksi kemudian data disajikan. Biasanya yang paling sering digunakan untuk menyajikan data dalam penelitian kualitatif adalah dengan teks yang bersifat naratif. Langkah yang terakhir dalam menganalisis data adalah penarikan kesimpulan. Kesimpulan dalam penelitian kualitatif mungkin dapat menjawab rumusan masalah yang dirumuskan sejak awal, tetapi mungkin juga tidak, karena masalah dan rumusan masalah dalam penelitian kualitatif masih bersifat sementara dan akan berkembang setelah penelitian berada di lapangan.

\section{PEMBAHASAN}

Kecamatan Brang Rea terletak di Timur Laut Sumbawa Barat. Dengan luas hutan negara yang mencapai 69 persen dan topografi wilayah yang berbukit. Kecamatan Brang Rea merupakan daerah resapan air yang ideal dan wilayah pertanian yang subur dengan ketersediaan air sepanjang tahun. Batas-batas Kecamatan Brang Rea antara lain: Sebelah Utara: Kec. Alas Barat Kab. Sumbawa; Sebelah Selatan: Kec. Brang Ene; Sebelah Barat: Kec. Taliwang; dan Sebelah Timur: Kec. Lunyuk. Luas Kecamatan Brang Rea tahun 2015 tercatat 211,09 $\mathrm{km}^{2}$ yang terbagi menjadi sembilan desa, yaitu Sapugara, Bree, Desa Beru, Tepat, Bangkat Monteh, Seminar Salit, Tepas Sepakat, Moteng, Lamuntet, dan Rarak Ronges. Dilihat dari jarak antara desa dengan ibukota kecamatan 8 desa yang ada di Kecamatan Brang Rea relatif dekat dengan pusat pemerintahan kecamatan, jarak tempuh berkisar antara 1 sampai 7 km. Berbeda halnya dengan Desa Rarak Ronges yang terletak di atas bukit dengan jarak tempuh mencapai $16 \mathrm{~km}$ dari pusat kecamatan. Tinggi Kecamatan Brang Rea dari permukaan air laut berkisar antara 125-700 m.

Desa Desa Beru dimana penelitian dilakukan dialiri aliran sungai sepanjang $2 \mathrm{~km}$. Berdasarkan pengamatan penulis, hal ini berpotensi tercemarnya air sungai oleh zat 
berbahaya. Penyebab terjadinya pencemaran air sungai karena masuknya mahluk hidup, zat, energi atau komponen lain kedalam air sehingga menyebabkan kualitas air tercemar. Air sering tercemar oleh berbagai komponen anorganik, di antaranya berbagai jenis logam berat yang berbahaya. Logam berat yang berbahaya yang mencemari lingkungan, yang terutama adalah Merkuri (Hg). Merkuri atau Raksa atau Air raksa (L atin: Hydrargyrum, air/cairan perak) adalah unsur kimia pada tabel periodik dengan simbol $\mathrm{Hg}$ dan nomor atom 80. Merkuri merupakan elemen alami, sering mencemari lingkungan. Kebanyakan merkuri yang terdapat di alam dalam bentuk senyawa dengan elemen lain dan jarang dijumpai dalam bentuk elemen terpisah. Komponen merkuri banyak tersebar di karang-karang, tanah, udara, air dan organisme hidup melalui prose fisika, kimia, dan biologi yang kompleks.

Berdasarkan pengamatan penulis, sarana kesehatan atau puskesmas yang berada di Kecamatan Brang Rea berjumlah satu unit. Lokasinya berada di Desa Desa Beru. Secara umum, pelayanan kesehatan yang diselenggarakan oleh puskesmas meliputi pelayanan kuratif (pengobatan), preventif (upaya pencegahan), promotif (peningkatan kesehatan) dan rehabilitasi (pemulihan kesehatan). Terkait masalah pencemaran merkuri di air sungai, sudah menjadi tanggung jawab Puskesmas Brang Rea untuk membantu masyarakat mulai dari upaya pencegahan, pengobatan, sampai pemulihan kesehatan. Sedangkan jumlah tenaga kesehatan di Desa Desa Beru sebanyak 10 orang. Kebanyakan dari mereka bertugas di Puskesmas Brang Rea. Namun ada juga beberapa orang yang bertugas di Dinas Kesehatan KSB. Tenaga kesehatan inilah yang menjadi garis depan atau corong pemerintah dalam menyosialisasikan tentang kesehatan, khususnya dalam hal ini bahaya zat merkuri bagi kesehatan. Berdasarkan wawancara yang penulis lakukan dengan informan kunci, sebagai salah satu pejabat di Puskesmas Brang Rea, menyebutkan:

"Saat ini yang menjadi isu utama kesehatan di wilayah Brang Rea adalah dampak merkuri yang digunakan pada pertambangan emas rakyat bagi kesehatan" (wawancara dengan Ibu Vivie Yuniarsih, S.Farm, Apt).

Penulis memahami bahwa kekayaan alam di NTB yang jadi incaran pengusaha dan rakyat di sana adalah emas. Pertambangan emas milik rakyat merupakan salah satu penunjang perekonomian masyarakat. Berdasarkan wawancara penulis dengan salah seorang penambang emas rakyat yang tidak mau disebutkan namanya (X), mengungkapkan: 
"Dengan bermodal Rp 150 juta saya sudah bisa mendapatkan emas di bebatuan yang nilainya terkadang mencapai Rp 300 juta per 3 minggu atau 21 hari jika aktivitas pengolahan bebatuan berjalan seperti biasa. Namun ketika menemukan kandungan emas yang banyak, maka ratusan juta bisa dikantongi dalam hitungan minggu”. (wawancara informan X).

Untuk mengambil dan mengolah bebatuan ini, informan ini mengakui tidak punya izin. Menurutnya, usaha ini dijalani secara ilegal (tidak ada izin). Selanjutnya ia tinggal beli (alat) kemudian pasang dan selesai. Walaupun bersifat ilegal, namun pemerintah masih memikirkan menyelesaikan polemik ini tanpa munculnya masalah. Pemerintah menyadari bahwa potensi alam di daerah tersebut sangat tinggi. Oleh karena itu, wajar apabila masyarakat tertarik menjalankan usaha ini.

Berdasarkan pengamatan penulis, maraknya aktivitas pertambangan tradisional yang tentunya ilegal itu dapat dilihat dari kejauhan. Terlihat adanya tenda-tenda di kawasan pegunungan di wilayah di Brang Rea. Hampir semua gunung dan bukit di wilayah itu digarap secara mandiri oleh penambang tradisional. Mereka meyakini bahwa gunung dan bukit itu memiliki kandungan logam emas dan perak serta perunggu. Selain itu, peralatan gelondongan (pemisah logam dengan tanah) juga nampak jelas menyebar di banyak lokasi.

Berdasarkan informasi yang penulis dapatkan dari berbagai sumber, jumlah gelondongan itu dapat mencapai 2.000 unit dan tersebar di banyak lokasi. Satu lokasi dapat mencapai 20 unit. Pemerintah tengah berupaya mengorganisir para penambang tradisional itu dan mewadahinya dalam bentuk koperasi. Koperasi tersebut yang akan membangun pabrik pengolahan material hasil tambang rakyat itu. Harapannya, ada investor yang bermitra dengan para penambang tradisional itu, dan pengurus koperasi yang akan mengorganisir penambang tradisional tersebut.

Seperti diketahui, hingga kini Pemerintah Provinsi NTB pun tengah menunggu penetapan Wilayah Pertambangan (WP) provinsi, sebagai rujukan untuk pengajuan usulan penetapan WPR di kabupaten/kota. Sepanjang belum ada WP provinsi yang ditetapkan Menteri Energi dan Sumber Daya Mineral (ESDM), maka WPR di kabupaten/kota pun belum bisa diajukan untuk ditetapkan. Kepala Dinas Pertambangan dan Energi (Distamben) Provinsi NTB Eko Bambang Sutedjo mengatakan, pihaknya sudah berkoordinasi dengan Kementerian ESDM terkait penetapan WP provinsi, sebagaimana diamanatkan Undang Undang Nomor 4 Tahun 2009 tentang Pertambangan Mineral dan Batubara (Minerba). Awal 2011 lalu, 
Pemprov NTB mengajukan usulan penetapan WP kepada Kementerian ESDM sebagai tindak lanjut dari Peraturan Pemerintah (PP) Nomor 22 Tahun 2010 tentang Wilayah Pertambangan dan PP Nomor 23 Tahun 2010 tentang Pelaksanaan Kegiatan Usaha Pertambangan. Menteri ESDM yang berkewenangan menetapkan WP di wilayah provinsi, namun baru akan menetapkan WP itu setelah mendapat persetujuan dari DPR. Tapi hingga kini DPR belum merampungkan kajiannya itu (Sumbawa2, 2012).

Minimnya pengetahuan tentang kesehatan dan lingkungan mengakibatkan tidak adanya standar operasional Analisis Mengenai Dampak Lingkungan (Amdal). Mengingat besarnya dampak yang disebabkan oleh aktivitas tambang, diperlukan upaya-upaya pengelolaan yang terencana dan terukur. Pengelolaan lingkungan di sektor pertambangan biasanya menganut prinsip Best Management Practice. Berdasarkan wawancara dengan informan kunci:

"Untuk memberikan edukasi kepada masyarakat tentang bahaya merkuri, Dinas Kesehatan KSB telah melakukan komunikasi kesehatan melalui metode komunikasi tatap muka, yaitu penyuluhan kesehatan". (wawancara dengan Ibu Vivie Yuniarsih, S.Farm, Apt)

Penyuluhan kesehatan diatur oleh pemerintah dalam Undang-undang Pasal 38 yakni UU Kesehatan Bab V tentang Upaya Kesehatan Tahun 2008:10 (Depkes RI, 2008) sebagai berikut: a. Penyuluhan kesehatan masyarakat diselenggarakan guna meningkatkan pengetahuan, kesadaran, kemauan, dan kemampuan masyarakat untuk hidup sehat, dan aktif berperan serta dalam upaya kesehatan; b. Ketentuan mengenai penyuluhan kesehatan sebagaimana dimaksud dalam ayat (1) ditetapkan dengan peraturan pemerintah.

Komunikator kesehatan dalam hal ini adalah penyuluh kesehatan di Puskesmas Brang Rea, dan yang bertindak sebagai komunikan adalah masyarakat Brang Rea KSB. Selanjutnya, pesan disampaikan secara langsung dari komunikator kepada komunikan dan kemudian secara langsung juga komunikator dapat menerima umpan balik (feedback) dari komunikan. Adapun keuntungan menggunakan komunikasi tatap muka adalah kita dapat menangkap respon balik atau umpan balik komunikan saat melakukan proses interaksi baik secara verbal maupun non verbal. Jika umpan balik yang diberikan bersifat positif, berarti pesan kita dapat diterima dengan baik oleh komunikan. Sebaliknya, bila respon bersifat negatif, maka kita sebagai komunikator harus memperbaiki cara penyampaian pesan yang dimaksud. Sedangkan kelemahan dari komunikasi tatap muka adalah ketidakefektifan waktu. Komunikator dan 
komunikan harus bertemu dalam melakukan proses komunikasi dan menghabiskan waktu bersama di sebuah tempat.

Menurut informan kunci, pesan dalam komunikasi kesehatan yang disampaikan tenaga penyuluh di Puskesmas Brang Rea antara lain:

"tentang bahaya merkuri bagi kesehatan, batas toleransi merkuri bagi tubuh, dan dampak jangka pendek dan panjang bagi kesehatan”. (wawancara dengan Ibu Vivie Yuniarsih, S.Farm, Apt)

Bila dirinci, maka pesan-pesan tersebut merujuk pada ketentuan umum batasan kandungan merkuri maksimum yaitu sebesar 0,005 ppm untuk makanan. Sedangkan WHO (World Health Organization) menetapkan batasan maksimum yang lebih rendah, yaitu 0,0001 ppm untuk air. Keracunan merkuri disebabkan oleh konsumsi ikan yang tercemar merkuri atau konsumsi biji-bijian yang diberi perlakuan dengan merkuri.

Komunikasi kesehatan memiliki manfaat yang sangat besar, baik bagi individu maupun bagi masyarakat. Bagi individu, komunikasi kesehatan dapat membantu menambah pengetahuan akan bahaya merkuri, membangkitkan motivasi untuk waspada serta meningkatkan kewaspadaan akan kesehatan dirinya. Bagi masyarakat, komunikasi kesehatan dapat menjadikan kesehatan sebagai isu dan topik yang penting sehingga dinamika akan informasi kesehatan dapat berkembang lebih cepat. Komunikasi kesehatan digunakan untuk meningkatkan kewaspadaan masyarakat akan penyakit, mendidik masyarakat akan penyakit, baik penyebab maupun pengobatannya, mengubah perilaku individu maupun masyarakat akan penyakit, mengubah perilaku individu untuk mencegah atau mengontrol penyebaran penyakit, advokasi dalam menciptakan norma sosial untuk meningkatkan cara hidup sehat. Sehingga kasus pencemaran air sungai oleh zat merkuri yang sudah terlanjur terjadi dapat ditanggulangi, seperti tidak mengonsumsi ikan yang berasal dari sungai, tidak mengambil air di sungai untuk mandi atau masak.

Untuk keefektifan dalam komunikasi kesehatan, diperlukan media agar pesan dapat tersampaikan dengan baik. Media komunikasi kesehatan telah mampu mempermudah manusia dalam melakukan interaksi dengan sosial lingkungannya. Media memiliki kekuatan memengaruhi kesehatan dengan membentuk perilaku hidup sehat, termasuk pikiran dan keyakinan tentang kesehatan pada tataran individu, agenda publik dan kelompok sosial, serta pada tataran institusional maupun sosial. Media yang digunakan dalam komunikasi kesehatan 
di Brang Rea adalah melalui poster. Menurut informan kunci, alasan penggunaan poster dikarenakan media ini mampu merepresentasikan maksud dan tujuan pemerintah melalui Dinas Kesehatan KSB dan petugas di Puskesmas Brang Rea. Penulis memahami bahwa poster sebagai media komunikasi luar ruang (outdoor) berisi pesan singkat dalam bentuk gambar dengan tujuan untuk memengaruhi seseorang agar tertarik pada sesuatu, atau memengaruhi agar seseorang bertindak akan sesuatu hal. Meskipun poster tidak dapat memberi pelajaran dengan sendirinya karena keterbatasan kata-kata. Maka poster lebih cocok kalau diperuntukkan sebagai tindak lanjut dari suatu pesan yang sudah disampaikan beberapa waktu yang lalu. Dengan demikian poster bertujuan untuk mengingat kembali dan mengarahkan pembaca ke arah tindakan tertentu sesuai dengan apa yang diinginkan oleh komunikator.

Dalam membuat poster untuk kegiatan komunikasi kesehatan perlu diperhatikan beberapa hal, diantaranya warna, huruf (tipografi), dan kesesuaian gambar dengan tulisan. Hal ini mengacu pada prinsip desain poster pada umumnya. Pemilihan warna dasar paling disukai pada sebuah poster adalah warna putih, hijau, merah, atau warna-warna yang cerah. Seperti pada gambar di bawah ini, poster berwarna dasar kuning dengan sedikit gradasi. Terdapat tulisan berwarna hitam dan merah, serta gambar percikan air yang menandakan mineral.

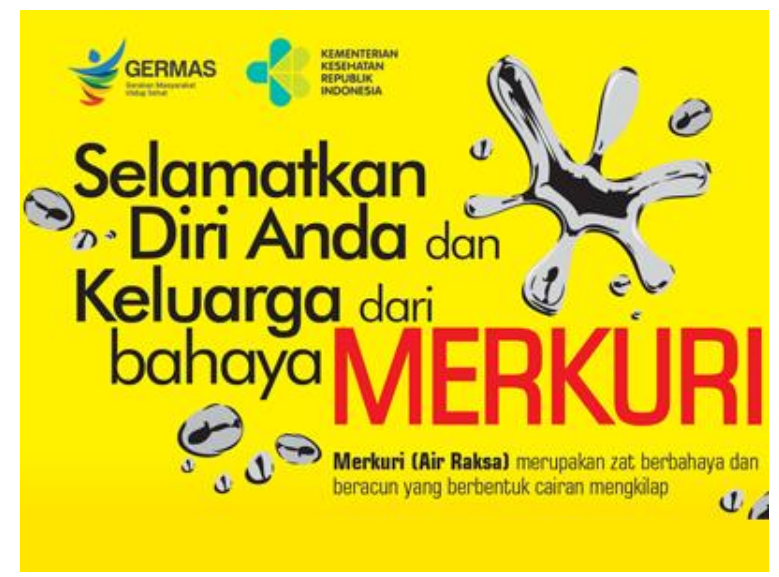

Gambar 2 Poster Bahaya Merkuri

Sumber: http://promkes.kemkes.go.id/poster--merkuri

Poster di atas berisi pesan "Selamatkan diri Anda dan keluarga dari bahaya Merkuri. Merkuri (air raksa) merupakan zat berbahaya dan beracun yang berbentuk cairan yang mengkilap". Menurut pemahaman penulis, hal ini dapat mengedukasi masyarakat tentang 
bahaya merkuri. Walaupun tidak ditulis secara spesifik jenis penyakit yang diakibatkan zat ini, karena ciri dari poster hanya memuat pesan yang singkat. Seperti yang dikemukakan oleh Suleman (1998), poster dan booklet merupakan media komunikasi yang termasuk dalam kategori media lini bawah (below the line media). Sesuai sifat yang melekat pada media lini bawah, pesan yang ditulis pada media tersebut berpedoman pada beberapa kriteria yaitu: menggunakan kalimat pendek, sederhana, singkat, ringkas, menggunakan huruf besar dan tebal. Selain itu, penggunaan huruf tidak kurang dari 10 pt, dikemas menarik dan kata yang digunakan ekonomis.

Alasan lain bahwa poster digunakan dalam komunikasi kesehatan di Brang Rea karena media ini dapat tahan lama, mencakup banyak orang, biaya tidak terlalu tinggi, tidak perlu energi listrik, dapat dibawa, mempermudah pemahaman, dan meningkatkan gairah belajar. Namun ada juga kelemahannya, yaitu tidak dapat menstimulasi efek suara dan efek gerak serta mudah terlipat, lecek, atau bahkan robek. Poster tentang bahaya merkuri diharapkan dapat memengaruhi masyarakat agar bertindak sesuai himbauan pemerintah. Maka perlu diperhatikan dalam menyusun kata-kata di dalam poster agar jelas dan tepat, serta dapat dengan mudah dibaca pada jarak kurang lebih 6 meter. Poster-poster ini biasanya ditempelkan pada suatu tempat yang mudah dilihat dan banyak dilalui orang, misalnya di dinding balai desa, pinggir jalan, papan pengumuman, kantor camat, dan sekolah-sekolah.

Poster lebih cocok digunakan sebagai tindak lanjut dari suatu pesan yang sudah disampaikan beberapa waktu yang lalu. Dengan demikian poster bertujuan untuk mengingatkan kembali dan mengarahkan pembaca ke arah tindakan tertentu sesuai dengan apa yang diinginkan oleh komunikator. Oleh sebab itu, poster sebagai media luar ruang berbentuk cetak dibuat semenarik dan seserdahana mungkin agar dapat dimengerti oleh para pembaca. Pada umumnya, karakteristik masyarakat di desa tidaklah sama dengan di kota. Ada hal-hal tertentu yang perlu diperhatikan, bahasanya lugas dan tidak terlalu tinggi.

Media komunikasi kesehatan cetak mempunyai dampak paling besar bagi upaya pengubahan perilaku kesehatan. Hal ini diperkuat dengan pernyataan yang dikemukakan oleh United States Departement of Health and Human Services (dalam Harahap dan Putra, 2019), yakni saluran media cetak seperti pamflet, selebaran, dan poster umumnya dianggap sebagai saluran yang paling baik untuk memberikan sebuah penguat kunci pesan-pesan komunukasi secara tepat waktu. Pamflet dan bahan grafis yang disebarkan pada tingkat individu atau 
keluarga dapat memberikan informasi yang kompleks dengan cara yang mudah dipahami, sehingga audiens sasaran dapat menggunakan informasi tersebut apabila sering diperlukan.

Karena informasi tentang bahaya merkuri cukup luas, maka kegiatan komunikasi kesehatan ini dilakukan secara bertahap. Dibuat sesederhana mungkin, namun tetap komprehensif sehingga masyarakat dapat mengetahuinya secara detail. Hasilnya, berdasarkan hasil wawancara penulis dengan informan kunci, masyarakat lambat-laun mulai mengindahkan informasi tersebut. Masyarakat mulai enggan mengonsumsi ikan dari sungai. Namun, masih ada sebagian kecil dari mereka yang tidak mempedulikannya. Rendahnya tingkat pendidikan masyarakat menyebabkan pola pikir mereka terbatas untuk menerima informasi baru, sehingga pemahaman tentang kesehatan pun kurang dan berdampak pada kesadaran untuk hidup sehat tidak tercapai. Komunikasi kesehatan memang memerlukan intervensi komunikasi untuk memperoleh objektivitas, termasuk memperkuat komunitas yang beresiko, advokasi, koalisi serta membangun konsensus untuk memperoleh kesehatan yang lebih baik. Selain itu, peran pemerintah untuk meningkatkan kualitas kesehatan masyarakat mutlak diperlukan.

\section{KESIMPULAN}

Solusi masalah kesehatan individu bukan sekedar memperbaiki masalah kerusakan fisik seperti pada pendekatan biomedis tetapi juga dalam banyak kasus kesehatan ternyata melibatkan kompleksitas kebutuhan, motivasi dan prioritas individu. Munculnya ilmu kesehatan dapat menciptakan pembangunan kesehatan yang baik. Informasi tentang kesehatan harus dipahami oleh semua orang tanpa terkecuali. Karena hidup sehat merupakan hak azasi bagi setiap orang. Hal ini yang mendorong pemerintah dalam menjalankan perannya sebagai pihak yang bertanggung jawab untuk mewujudkan pembangunan kesehatan yang baik dan merata. Kesehatan menjadi salah satu isu penting dalam pembangunan yang berorientasi pada manusia. Sektor ini menjadi barometer dalam melihat tingkat kemajuan suatu daerah.

Melalui tenaga kesehatan di Kecamatan Brang Rea, Dinas Kesehatan NTB melakukan komunikasi kesehatan dengan metode komunikasi tatap muka berupa penyuluhan kesehatan tentang bahaya merkuri. Selain penyuluhan, pemerintah membuat media luar ruang berupa poster sebagai saluran promosi kesehatan. Poster tentang bahaya merkuri ini ditempatkan di 
beberapa titik yang dianggap efektif untuk dibaca oleh masyarakat, seperti di puskesmas, balai desa, dan sekolah-sekolah.

Pemerintah diharapkan membuat regulasi yang dapat mengatur pertambangan rakyat sehingga tidak menimbulkan dampal negatif bagi lingkungan dan kesehatan, namun tetap memperhatikan perekonomian masyarakat khusunya di Brang Rea. Regulasi-regulasi tersebut diharapkan tidak berbenturan antara tradisi adat dan program kesehatan yang diupayakan dapat berjalan sinergis dalam upaya mewujudkan peningkatan derajat kesehatan masyarakat setinggi-tingginya melalui pelestarian budaya dan kearifan lokal setempat, sehingga regulasi ini dapat diterima, didukung, dan dijalankan oleh masyarakat.

\section{DAFTAR PUSTAKA}

Badan Pusat Statistik Kabupaten Sumbawa Barat. (2015). Katalog BPS. Kabupaten Sumbawa Barat: BPS KSB

Bensing, J.M. dan Verhaak P.F.M. (2004). Communication in medical encounters: Towards a health psychologyperspective. In: A Kaptein and J Weinman (Eds). Health Psychology, an introduction. Blackwell

Berry, Dianne. (2007). Healthy Communication Theory \& Practice. London: Open University Press.

Bobrow and Matson. (2003). "Theorising About Health Communication" dalam Handbook of Health Communication oleh Thompson, Dorsey, Miller, dan Parrot (ed). London: Lawrence erlbaum Associates.

Creswell, J.W. (2010). Research Design Pendekatan Kualitatif, Kuantitatif, dan Mixed. Yogyakarta: Pustaka Pelajar.

Denzin, N.K. \& Lincoln, Y.S. (2009). Handbook of Qualitative Research. Yogyakarta: Pustaka Pelajar.

Effendy, Onong Uchjana. (2003). Ilmu, Teori dan Filsafat Komunikasi. Bandung: Citra Aditya Bakti.

Kotler \& Zaltman. (1971). "Social Marketing: An Approach to Planned Social Change" dimuat dalam Journal of Marketing Vol. 35: (3-12).

Littlejohn, Stephen W. \& Karen Foss. (2009). Encyclopedia of Communication Theory I. London: Sage Publication.

Mulyana, Deddy. (2008). Komunikasi Efektif. Bandung: PT. Remaja Rosdakarya. 
Mubarak dan Wahit Iqbal. (2009). Komunikasi dalam Keperawatan. Jakarta: Salemba Medika.

Notoatmodjo, Soekijo. (2005). Promosi Kesehatan, Teori dan Aplikasi. Jakarta: Rineka Cipta.

Pusat Komunikasi Bisnis Universitas Mercu Buana. (2013). Prosiding Komunikasi Indonesia Untuk Membangun Peradaban Bangsa. Palembang: Puskombis Universitas Mercu Buana.

Schivo, Renata. (2007). Health Communication, From theory to Practice. San Francisco: John Wiley \& Sons, Inc.

Pace, R. Wayne dan Don F. Faules. (2002). Komunikasi Organisasi: Strategi Meningkatkan Kinerja Perusahaan, terjemahan Deddy Mulyana dkk, editor Deddy Mulyana. Bandung: Remaja Rosda Karya.

Rakhmat, Jallaludin. (2000). Metode Penelitian Komunikasi. Bandung: PT. Remaja Rosdakarya

Rozak. (2019). Dikes KSB Bersama Polri Lakukan Sosialisasi Bahaya Mercury. (Online), (https://beritalima.com/dikes-ksb-bersama-polri-lakukan-sosialisasi-bahayanyamercury/, diakses tanggal 30 September 2019)

Sumbawa2. (2012). Pertambangan Tradisional di Sumbawa Barat Makin Marak. (Online), (http://sumbawabaratnews.com/?p=6021, diakses tanggal 20 September 2019).

Tubbs, Stewart L. dan Sylvia Moss. (2000). Human Communication; Konteks - Konteks Komunikasi, Buku I dan Buku II, terjemahan Deddy Mulyana dan Gembirasari, Bandung: PT. Remaja Rosda Karya.

West, Richard dan Turner, Lynn H., (2008). Pengantar Teori Komunikasi Analisis dan Aplikasi (Introducing Communication Theory: Analysis and Application). Jakarta: McGraw-Hill - Salemba Humanika 